\title{
Differential Regulation of Glucocorticoid Receptor Expression by Ligand in Fetal Rat Lung Cells
}

\author{
NEIL SWEEZEY, CAROLYN MAWDSLEY, FELICIA GHIBU, LI SONG, SHILPA BUCH, \\ AIDEEN MOORE, TONY ANTAKLY, AND MARTIN POST
}

\begin{abstract}
Neonatology Research, The Hospital for Sick Children Research Institute, University of Toronto, Toronto, Ontario [C.M., L.S., S.P., A.M., M.P.], and The McGill University-Montreal Children's Hospital Research Institute [N.S., F.G.] and Département de Pathologie, Université de Montréal, Montréal, Québec, Canada [T.A.]
\end{abstract}

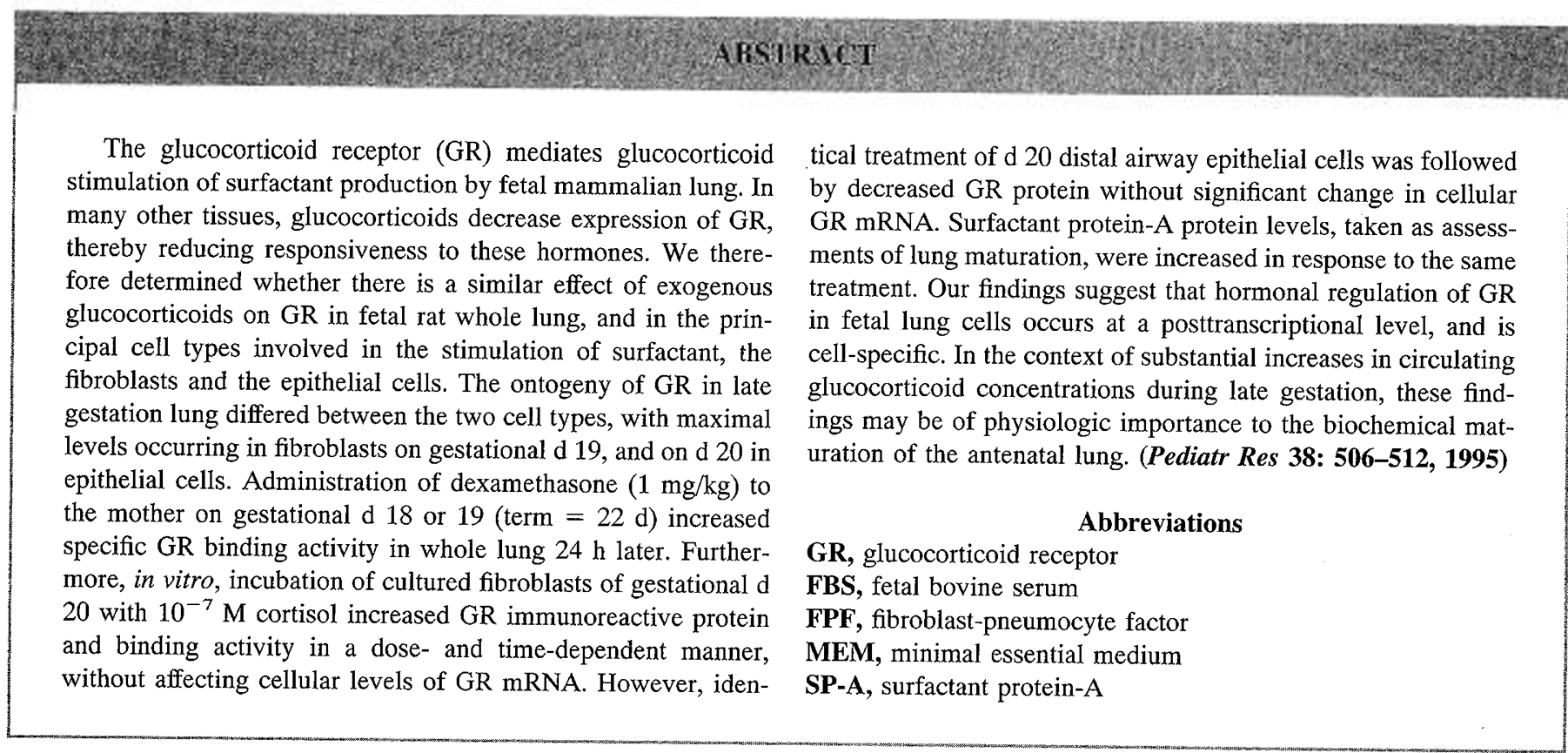

Glucocorticoids accelerate the onset of mature levels of surfactant synthesis by fetal mammalian lung (1-3) via the classic GR mechanism (1, 2, 4-9). However, in many tissues, glucocorticoids decrease GR expression, thereby decreasing tissue responsiveness to glucocorticoid stimulation. The effect of glucocorticoids on GR in late gestation fetal lung around the time of the onset of augmented surfactant production is incompletely understood.

Administration of glucocorticoids decreases GR mRNA (10) and GR protein (11) in several adult rat organs, including lung. In various cell lines, glucocorticoids lower GR number by decreasing GR transcription rates without altering affinity for ligand $(12,13)$. However, it is recognized that the response of GR mRNA steady-state levels to glucocorticoid treatment can

Received July 21, 1994; accepted April 4, 1995.

Correspondence and reprint requests: Neil Sweezey, Respiratory Medicine, The Hospital for Sick Children, 555 University Avenue, Toronto, Ontario M5G 1X8, Canada.

Supported in part by Medical Research Council of Canada Grant PG-42 (to M.P.) and MT-7959 (to T.A.), and by the Association pulmonaire du Québec and the McGill University-Montreal Children's Hospital Research Institute (to N.S.). vary as a function of cell type. Pépin et al. (14) found dexamethasone caused a decrease in GR mRNA in hypothalamic neurones, but an increase in GR mRNA in cerebral cortex neurones. Treatment of a steroid-sensitive subclone of a human lymphoid cell line causes an increase in GR protein and in GR mRNA, but the same treatment brings about no change in GR protein or GR mRNA levels in a steroid-resistant subclone (15). Furthermore, it is also recognized that the response of GR to glucocorticoid stimulation can depend on stage of development. Kalinyak et al. (16) reported a glucocorticoid induced decrease in GR mRNA levels in postnatal brain and liver, but no change in the corresponding fetal tissues. There are parallel increases in late gestation fetal lung in both glucocorticoid hormone concentration (1) and GR number (without any apparent change in affinity for ligand) $(17,18)$, suggesting that glucocorticoids may not regulate fetal lung GR gene expression by a feedback down-regulatory mechanism.

In the present study of fetal rat lung during late gestation, we investigated the ontogeny and response to glucocorticoids of GR in whole lung, in fibroblasts, and in distal airway epithelial 
cells. These cell types were of interest because production of surfactant by epithelial cells seems to be augmented by a differentiation factor elaborated by fetal lung fibroblasts (FPF) in response to glucocorticoids (19-21).

\section{METHODS}

Materials. $\left[6,7-{ }^{3} \mathrm{H}(\mathrm{N})\right]$ Triamcinolone acetonide $(9 \mathrm{Ci} /$ mmol) was obtained from Dupont Canada (NEN Research Products) (Mississauga, Ontario). D- $\left[\alpha-{ }^{32} \mathrm{P}\right] \mathrm{CTP}(3000 \mathrm{Ci} /$ $\mathrm{mmol}$ ), nylon (Hybond $\mathrm{N}$ ) membranes, and random primer labeling systems were purchased from Amersham Canada (Oakville, Ontario), and restriction enzymes, dextran sulfate, prepackaged disposable (Sephadex) columns, and blue Sepharose 6B-CL from Pharmacia (Baie D'Urfé, Quebec). All other chemicals were purchased from Sigma Chemical Co. (St. Louis, MO). A construct named pRd N93, containing the open reading frame for the $2.3-\mathrm{kb}$ rat GR cDNA (except for the 19-glutamine repeat, which was excised) inserted into the BamHI site of the plasmid pSP64, was a gift of Dr. Yamamoto (University of California, San Francisco). A 1.5 -kb $\beta$-actin cDNA derived from the 2-kb cDNA (Al) of Dr. D. W. Cleveland et al. (21a) was used to monitor evenness of loading and transfer of RNA in Northern blot analyses. MEM (glucocorticoid-free) and FBS were obtained from GIBCO/BRL (Burlington, Ontario).

Animals. Wistar rats were obtained from Charles River (St. Constant, Quebec) and were bred in the Lab Animal Services facilities of The Hospital for Sick Children, Toronto. Pregnant dams of known gestational age $(\mathrm{d} 0=$ mating; term $=\mathrm{d} 22)$ were killed with diethylether. The fetuses were immediately removed from the uterus, and the fetal lungs dissected out. For whole lung studies, they were then flash frozen in liquid nitrogen, and stored at $-70^{\circ} \mathrm{C}$ until used for RNA isolation and cytosol generation. Cell culture was performed as described below. In comparing the data from fetal lung with data from adult lung, binding assays were performed on nonpregnant adult rat lung rather than on the maternal lung of the fetal samples to avoid the possibility of confounding effects from the altered hormonal milieu of the pregnant state.

Cell culture. Fibroblasts and epithelial cells were isolated from the fetal lungs as described in detail previously (22). Briefly, the lung tissue was digested for $20 \mathrm{~min}$ in $0.0625 \%$ trypsin and $0.4 \mathrm{mg} / \mathrm{mL}$ DNAse. Then these enzymes were neutralized with MEM $+10 \%$ FBS, and the mixture was filtered through a $100-\mu \mathrm{m}$ mesh nylon bolting cloth and centrifuged. The pellet was resuspended in MEM containing 0.1\% collagenase. After $15 \mathrm{~min}$ of incubation, the collagenase activity was neutralized by adding MEM $+10 \%$ FBS. Fibroblasts were allowed to adhere to tissue culture flasks during two incubations of $1 \mathrm{~h}$ each. The nonadherent cells were transferred to new culture flasks and incubated overnight for attachment of epithelial cells. Nonadherent cells were removed from all cell cultures after overnight incubation. Cells were grown to confluence in MEM $+10 \%$ FBS, and then thoroughly rinsed in MEM (serum- and glucocorticoid-free). For studies of ontogeny, or for controls in studies of the effects of hormones, the cells were then incubated in MEM alone. Cells incubated in MEM plus a specified concentration of cortisol were in all other respects handled exactly as were the MEM controls. All experiments were performed $24-48 \mathrm{~h}$ after isolation. Viability and purity of the cultures were comparable to previously published data (22). In previous studies, we have shown that the epithelial cells express phenotypic features of type II cells, and possess antigenic determinants of mature type II cells (22).

Glucocorticoid receptor binding assay. Most studies now support the hypothesis that the GR is cytosolic, translocating to the nucleus after binding to specific ligand (9). Therefore, we measured the amount of specific GR binding activity in cytosol, according to the method of Wrange et al. (23). Briefly, fetal lung tissue or cells were homogenized in an equal volume of $1 \mathrm{mM}$ EDTA, $10 \%$ (wt/vol) glycerol, $10 \mathrm{mM}$ DTT, $20 \mathrm{mM}$ sodium phosphate $(\mathrm{pH} 7)$, and $50 \mathrm{mM}$ sodium chloride $(\mathrm{pH}$ 7.0) using a Dounce homogenizer. Cytosol was prepared by centrifuging the homogenate at $100000 \times g$ for $60 \mathrm{~min}$ at $4^{\circ} \mathrm{C}$. Avoiding the floating layer of fat, the clear supernatant was retained as cytosol. Protein content of the cytosol was assayed by the method of Bradford (24). Cytosol $(200 \mu \mathrm{L})$ was incubated for $16 \mathrm{~h}$ at $4^{\circ} \mathrm{C}$ with $800 \mu \mathrm{L}$ of $\mathrm{H}_{2} \mathrm{O}, 5 \mu \mathrm{L}$ of $\left[{ }^{3} \mathrm{H}\right]$ triamcinolone acetonide, and $50 \mu \mathrm{L}$ of either DMSO (total binding) or $2 \mathrm{mg}$ of triamcinolone acetonide/mL DMSO (nonspecific binding). The excess of unbound $\left[{ }^{3} \mathrm{H}\right]$ triamcinolone acetonide was then removed by incubation for $5 \mathrm{~min}$ at $4^{\circ} \mathrm{C}$ with a one-third volume of aqueous $3 \%(\mathrm{wt} / \mathrm{vol})$ activated charcoal in $0.3 \%$ (wt/vol) dextran sulfate, followed by centrifugation at $12000 \times g$ at $4^{\circ} \mathrm{C}$ for $15 \mathrm{~min}$. An aliquot of the supernatant was then counted in a Rackßeta 1219 liquid scintillation counter with automated correction for quenching (LKB, Bromma, Sweden). Specific cytosolic GR binding activity (expressed as femtomoles per mg of protein) was saturable, with little additional specific binding noted above $20 \mathrm{nM}$ $\left[{ }^{3} \mathrm{H}\right]$ triamcinolone acetonide (Fig. 1). Nonspecific binding was $<10 \%$ in both control and dexamethasone-treated groups. Incubation of the cytosol with $\left[{ }^{3} \mathrm{H}\right]$ triamcinolone acetonide at $4^{\circ} \mathrm{C}$ for $16 \mathrm{~h}$ increased binding by $10-20 \%$ compared with incubation for $4 \mathrm{~h}$, in good agreement with the findings of Carbone et al. (25), who studied GR binding in d 21 fetal rat epiphyseal chondrocytes using the same radioligand.

GR RIA. Cellular GR protein content was measured by RIA as previously described in detail $(11,15)$. The RIA uses a rabbit antiserum (14B2) raised against a 14-amino acid peptide (14-mer) of the amino terminus domain of the human GR. It is a simple and specific RIA to quantitate both human and rat GR, which detects both activated and inactivated GR (11). Briefly, after dissociation from monolayer, cell suspensions were collected by centrifugation, washed, and resuspended in ice-cold homogenate buffer containing $25 \mathrm{mM}$ Tris- $\mathrm{HCl}$ (pH7.4), 10 $\mathrm{mM} \mathrm{NaCl}, 2 \mathrm{mM} \mathrm{MgCl} 2,1 \mathrm{mM}$ EDTA, $5 \mathrm{mM}$ EGTA, $10 \mathrm{mM}$ leupeptin, and $5 \mathrm{mM}$ DTT in $0.1 \%$ (vol/vol) Triton. Cells were homogenized using a ground glass homogenizer. Homogenates were centrifuged at $100000 \times \mathrm{g}$ for $20 \mathrm{~min}$ at $4^{\circ} \mathrm{C}$, and the supernatants were frozen at $-70^{\circ} \mathrm{C}$ until assayed. Total protein content was using a Bio-Rad protein assay (Bio-Rad, Richmond, CA). The standard buffer of RIA consists of PBS containing $0.1 \%$ nonimmune rabbit serum. The RIA was per- 
A

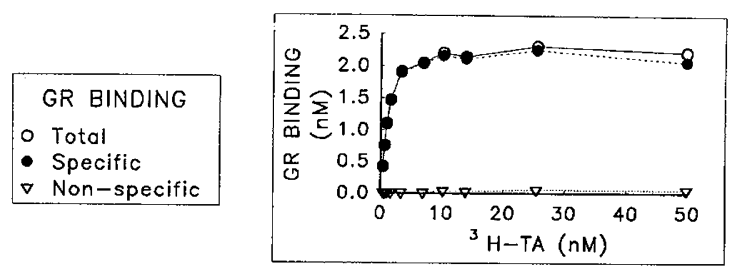

B

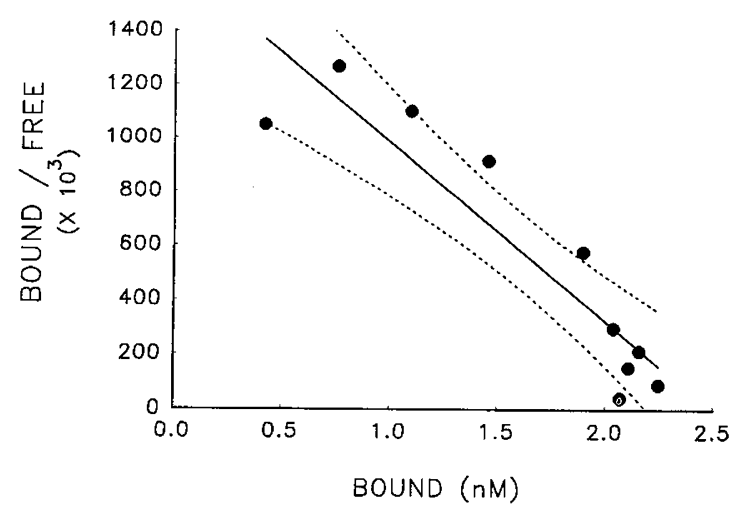

Figure 1. Scatchard analyses of GR binding activity in $\mathrm{d} 21$ fetal rat whole lung. Representative data, with least squares' regression and $95 \%$ confidence intervals. Inset, GR binding as a function of ligand concentration. Apparent dissociation constant $\left(\mathrm{k}_{\mathrm{d}}\right):(1.5 \pm 1) \mathrm{nM}(\mathrm{d} 21)$. Ligand: triamcinolone acetonide $(T A)$.

formed in polystyrene tubes; $50 \mu \mathrm{L}$ of 14-mer GR standards were added to $100 \mu \mathrm{L}$ of standard buffer containing 20000 cpm of ${ }^{125} \mathrm{I}-14$-mer and $100 \mu \mathrm{L}$ of the diluted anti-14-mer. After incubation at $22^{\circ} \mathrm{C}$ for $1 \mathrm{~h}, 100 \mu \mathrm{L}$ of goat anti-rabbit antiserum (Biomega, Montreal) tested at various dilutions were added. The tubes were incubated at $4^{\circ} \mathrm{C}$ overnight $(14-18 \mathrm{~h})$, then $1 \mathrm{~mL}$ of ice-cold standard buffer was added before centrifugation at $5000 \times g$ for $30 \mathrm{~min}$ at $4^{\circ} \mathrm{C}$. The supernatant was discarded, the radioactivity of the precipitate left in the tubes was counted in an LKB-Wallac (Sweden) Compugamma, and RIA data were calculated by the RIA program provided with the counter.

Rat $\boldsymbol{S P}$-A isolation. Fetal lung GR levels were correlated with levels of SP-A, a glucocorticoid-responsive gene in developing rat lung (26-28) which is a marker of epithelial type II cell development.

SP-A was isolated from bronchoalveolar lavage fluid of rats. Routinely, 20 adult rat lungs were lavaged twice with $10 \mathrm{~mL}$ of $0.9 \%(\mathrm{wt} / \mathrm{vol}) \mathrm{NaCl}$ per rat. The lavage fluid was centrifuged at $300 \times g$ for $10 \mathrm{~min}$, and the supernatant was collected and spun at $20000 \times g$ for $20 \mathrm{~min}$ at $4^{\circ} \mathrm{C}$. The supernatant was decanted, and the pellet was washed in $2 \mathrm{~mL}$ of $0.15 \mathrm{M} \mathrm{NaCl}$, $0.1 \mathrm{mM}$ EDTA, $5 \mathrm{mM}$ Tris, $\mathrm{pH}$ 7.4, $0.2 \mathrm{mM}$ DTT, $1 \mathrm{mM}$ phenylmethylsulfonyl fluoride, and then extracted with $100 \mathrm{~mL}$ of $n$-butanol. After $1 \mathrm{~h}$ of stirring at room temperature, the butanol extract was centrifuged at $3000 \times g$ for $10 \mathrm{~min}$. The supernatant was removed, and the remaining pellet (crude surfactant) was washed several times with $100 \mathrm{mM} \mathrm{NaCl}, 5$ $\mathrm{mM}$ Tris, $\mathrm{pH} 7.4,20 \mathrm{mM}$ octyl- $\beta$-D-glucopyranoside and then resuspended in $5 \mathrm{mM}$ HEPES, $\mathrm{pH}$ 7.4. The suspension was dialyzed for $48 \mathrm{~h}$ against HEPES, $\mathrm{pH} 7.4$, and centrifuged at $100000 \times g$ for $60 \mathrm{~min}$, and the supernatant was collected.
The extracted proteins were eluted through pd10 columns followed by blue Sepharose CL-6B columns to remove any. residual serum proteins. The filtrate, which contained mainly rat SP-A as determined by SDS-gel electrophoresis, was concentrated and stored in small aliquots at $-70^{\circ} \mathrm{C}$.

Determination of SP-A content. A polyclonal antibody raised against rat SP-A was produced by inoculating rabbits with $200 \mu \mathrm{g}$ of crude surfactant protein in Freund's complete adjuvant. Boosts with $100 \mu \mathrm{g}$ of purified SP-A were given on a 2-wk basis in incomplete Freund's adjuvant. Serum from injected rabbits was tested by Western blotting. Onedimensional SDS-PAGE was performed by the method of Laemmli (29) using 1-mm thick gels containing $15 \%$ polyacrylamide. Electrophoretic transfer of proteins from polyacrylamide gels to nitrocellulose was performed according to Towbin et al. (30), after immunostaining with rabbit anti-rat SP-A (1:200), goat anti-rabbit $\operatorname{IgG}(1: 150)$, and rabbit peroxidase anti-peroxidase (1:500). The IgG fraction of this antiserum was used for ELISA, and it recognized only rat SP-A molecules with molecular masses of approximately 28,32 , and $38 \mathrm{kD}$ on Western blotting (Fig. 2). Similar rat SP-A sizes have been published previously (31). This antibody does not recognize any fetal liver or intestinal epitopes similar to SP-A, but does recognize epithelial type II cells in the adult rat lung (Fig. 2). The method for the ELISA was similar to that described by Ballard et al. (32). Standard curves were constructed from the absorbance of known amounts of rat SP-A, and sample values were calculated from the dilutions that fell on a linear part of the standard curve. As little as $0.5 \mathrm{ng}$ of SP-A in a sample could reliably be detected by this technique. ELISA were performed in triplicate from three different samples, and data are expressed per milligram of total protein.

RNA analysis. Total (nuclear and cytoplasmic) RNA was isolated by lysing the tissue in $4 \mathrm{M}$ guanidinium isothiocyanate followed by centrifugation on a $5.7 \mathrm{M}$ cesium chloride cushion to pellet RNA (33). After extraction with phenol:chloroform: isoamyl alcohol $(25: 24: 1, \mathrm{vol} / \mathrm{vol})$ and reextraction with chlo-
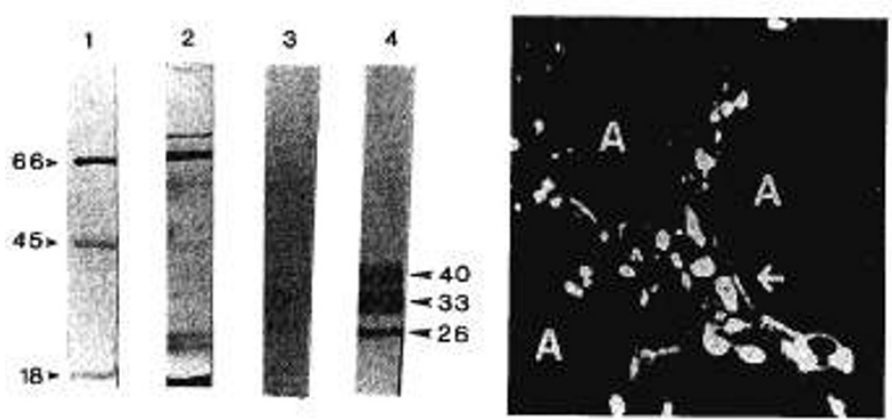

Figure 2. Specificity of rat SP-A antibody. (Left panel) Western blot immunoanalysis of SP-A in rat lung surfactant. Surfactant, isolated from bronchoalveolar lavage fluid of adult rats by centrifugation, was loaded $(10 \mu \mathrm{g}$ of protein) and separated on $15 \%(\mathrm{wt} / \mathrm{vol})$ polyacrylamide gel under reducing conditions. Protein was transferred to a nitrocellulose membrane and immunostained with either preimmune serum (lane 3) or anti-rat SP-A (lane 4); protein bands were detected at 40,33 , and $26 \mathrm{kD}$. Similar sized bands were detected in total protein extracts from whole lung (data not shown). Lane 1 shows molecular weight markers and lane 2 a Coomassie Blue staining. (Right panel) Immunolocalization of SP-A in adult rat lung. Epithelial type II cells show positive immunoreactivity to SP-A (arrow). $A=$ alveolar space. 
roform alone, the RNA was ethanol-precipitated, collected by centrifugation, lyophilized, and dissolved in water. RNA integrity was confirmed by fractionation on $1 \%$ (wt/vol) agaroseformaldehyde gels and staining the ribosomal RNA bands with ethidium bromide.

In slot blot analysis, aliquots of RNA (5.0-0.625 $\mu \mathrm{g} /$ sample) were serially diluted in a final $50 \mu \mathrm{L}$ solution of 6.15 $\mathrm{M}$ formaldehyde and $10 \times \mathrm{SSC}(1.5 \mathrm{M}$ sodium chloride, 0.15 $\mathrm{M}$ sodium citrate, $\mathrm{pH} 7.0$ ). The RNA was denatured at $65^{\circ} \mathrm{C}$ for $15 \mathrm{~min}$ and immediately immobilized on a nylon membrane under low vacuum filtration. After the solution had filtered through, the wells were rinsed with $500 \mu \mathrm{L}$ of $10 \times \mathrm{SSC}$, and RNA was fixed by baking at $80^{\circ} \mathrm{C}$ for $2 \mathrm{~h}$. The linearity of the slot blot assays was confirmed by serial dilution and the specificity by Northern blot analysis. For Northern blot analysis, $20 \mu \mathrm{g}$ of total RNA were fractionated on $1.0 \%$ (wt/vol) agarose gels containing $6 \%$ (vol/vol) formaldehyde, transferred to a nylon membrane, and then fixed by baking at $80^{\circ} \mathrm{C}$ for 2 h. GR and $\beta$-actin cDNA were labeled with $\mathrm{D}-\left[\alpha-{ }^{32} \mathrm{P}\right] \mathrm{CTP}$ by random hexamer priming with the Klenow fragment of Escherichia coli DNA polymerase I. Prehybridization $(1 \mathrm{~h}$ overnight) and hybridization (24-48 h) were performed in $50 \%$ (vol/vol) formamide, $750 \mathrm{mM} \mathrm{NaCl}, 75 \mathrm{mM}$ sodium citrate, 5 $\times$ Denhardt's solution $[0.4 \%(\mathrm{wt} / \mathrm{vol})$ each of BSA, Ficoll, and polyvinylpyrrolidone], $10 \%$ (wt/vol) dextran sulfate, and 100 $\mu \mathrm{g} / \mathrm{mL}$ denatured salmon sperm DNA at $42^{\circ} \mathrm{C}$. Blots were washed in $5 \times \mathrm{SSC}, 0.1 \%$ (wt/vol) SDS at $42^{\circ} \mathrm{C}$ for $20 \mathrm{~min}$, followed by $1 \times \mathrm{SSC}, 0.1 \% \mathrm{SDS}$ at $42^{\circ} \mathrm{C}$ for $15 \mathrm{~min}$, and then exposed to Kodak XAR-5 film using Dupont Cronex intensifying screens. The mRNA detected was quantified by an Ultrascan XL laser densitometer (LKB, Bromma, Sweden). Multiple exposure times were obtained to ensure that the autoradiographs were in the linear range for quantitative scanning.

Data presentation. Values are presented as the mean $\pm \mathrm{SE}$. Statistical significance $(p<0.05)$ was determined by an analysis of variance followed by assessment of differences using Dunnet's two-sided test (34), or Duncan's multiple range test (35).

\section{RESULTS}

Changes in lung GR during ontogeny. In whole fetal rat lung, steady-state GR mRNA levels were relatively low on d 18. On gestational d 19, there is a short-lived increase in GR mRNA, abruptly followed ( $\mathrm{d} 20-22)$ by a return of the mRNA to levels present before d 19 (Fig. 3). Specific GR ligand binding increased progressively from d 19 to $\mathrm{d} 21$ of gestation (Fig. 3). On Northern blot analysis of total RNA from fetal rat whole lung, rat GR cDNA hybridized to a 7-kb mRNA species (Fig. 3, inset), consistent with published data $(10,16)$. Scatchard analyses revealed that the apparent dissociation constant $\left(\mathrm{k}_{\mathrm{d}}\right)$ of GR did not change significantly with advancing gestation (d 19: $\mathrm{k}_{\mathrm{d}}=1.7 \pm 1 \mathrm{nM} ; \mathrm{d} 21: \mathrm{k}_{\mathrm{d}}=1.5 \pm 1 \mathrm{nM}$, mean \pm $\mathrm{SEM}, n=3$ independent experiments). The $\mathrm{k}_{\mathrm{d}}$ value for $\left[{ }^{3} \mathrm{H}\right]$ triamcinolone acetonide binding in whole fetal rat lung is similar to values published previously for $\left[{ }^{3} \mathrm{H}\right]$ dexamethasone binding (18).

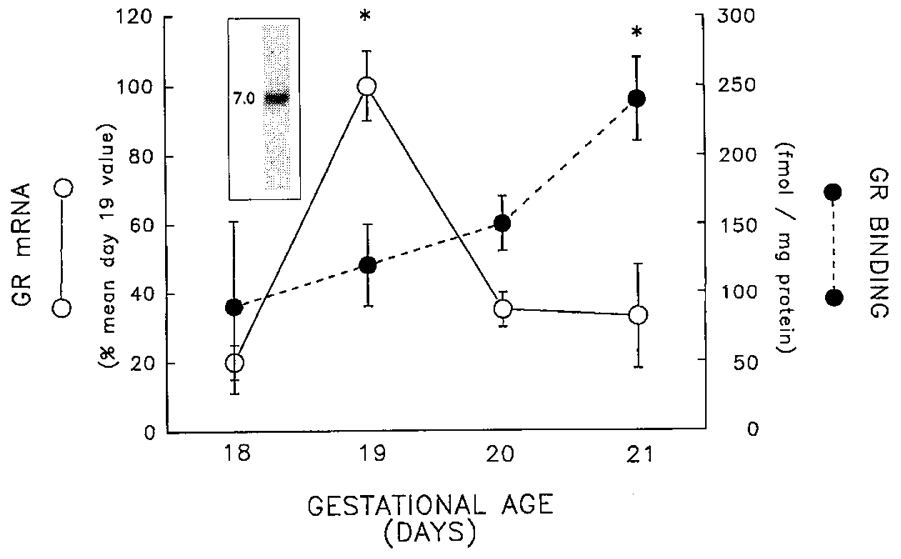

Figure 3. Developmental profiles of GR in fetal rat whole lung. GR mRNA levels $(O)$. Hybridization of specific GR probe to Northern blots of total RNA from whole lungs of $18-21 \mathrm{~d}$ of gestation. Data normalized for $\beta$-actin mRNA levels to control for mRNA loading and transfer. Mean $\pm \mathrm{SE}, n=3$ independent experiments for each data point (lungs from at least two litters were pooled in each experiment). Inset, GR mRNA, $7 \mathrm{~kb}$. Glucocorticoid binding activity (-). Cytosolic glucocorticoid binding activity, 18-21 d of gestation. Mean $\pm \mathrm{SE}, n=3$ independent experiments carried out in triplicate (lungs from at least two litters were pooled in each experiment); *significantly different $(p<0.05)$ from d 18 value.

In fibroblasts, GR mRNA levels were maximal at $19 \mathrm{~d}$ of gestation, accompanied by maximal GR binding activity on $\mathrm{d}$ 19 and 20 (Fig. 4A). In distal airway epithelial cells, GR mRNA levels and GR binding activity each peaked at $20 \mathrm{~d}$ of gestation (Fig. 4B). In both cell types, maximal GR binding activity represented substantial ( $\approx 4$-fold) increases over immature (d 18) activity. Furthermore, GR mRNA levels were highly variable on d 19 (epithelial cells) and 20 (fibroblasts).

Regulation of GR by glucocorticoid hormone. Whole lung GR mRNA levels were not changed by in utero exposure to glucocorticoids (Fig. 5A), but GR binding activity was increased. A single injection of $1 \mathrm{mg}$ of dexamethasone $/ \mathrm{kg}$ to the mother, $24 \mathrm{~h}$ before killing, increased d 20 fetal rat lung GR

A FIBROBLASTS

B EPITHELIAL CELLS
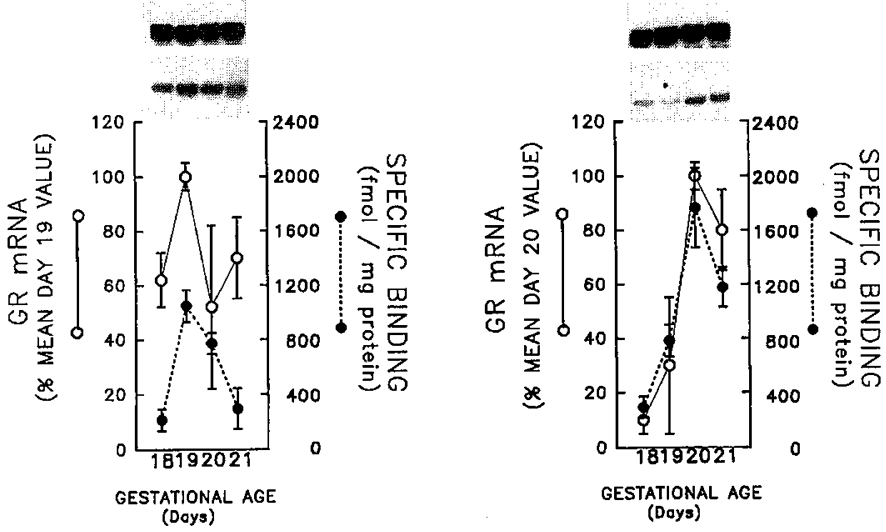

Figure 4. Developmental profiles of GR in fetal rat lung cells. (A) Fibroblasts; $(B)$ epithelial cells from distal airway. Upper inset, autoradiograph of $\beta$-actin mRNA; lower inset, GR mRNA, same representative blot. GR mRNA levels $(O)$ : Quantitation using laser densitometry, normalized for $\beta$-actin. Mean \pm SEM. For each data point, $n=3$ independent experiments. Glucocorticoid binding activity $(\bullet)$ : Mean \pm SEM. For each data point, $n=16$ fetuses, from four litters, in two independent experiments. 


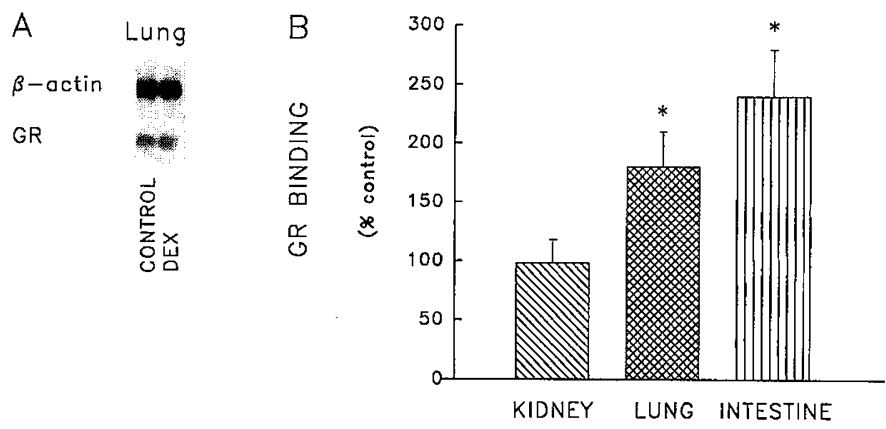

Figure 5. (A) Lack of effect of glucocorticoid on GR mRNA levels in fetal whole lung. GR mRNA levels were unaltered by maternal administration of dexamethasone. $D E X=$ dexamethasone $1 \mathrm{mg} / \mathrm{kg}$ in $200 \mu \mathrm{L}$ of DMSO intraperitoneally to pregnant rat $24 \mathrm{~h}$ before sacrifice; control $=200 \mu \mathrm{L}$ of DMSO only; $n=3$. (B) Tissue dependence of effect of glucocorticoid on GR binding activity. Foregut-derived tissues (lung or intestine) increased GR binding activity in response to dex, whereas urogenital ridge-derived tissue (kidney) did not. *Significantly different $(p<0.05)$ from control value; $n=3$.

binding activity (175 $\pm 20 \%$ of control, mean $\pm \mathrm{SD}, n=5$, $p<0.05$, dexamethasone versus DMSO control) (Fig. $5 B$ ). Two consecutive daily injections of dexamethasone (d 18 and 19) before sacrifice (d 20) further increased GR binding activity to $240 \pm 40 \%$ of control (not shown). The stimulatory effect of dexamethasone on GR binding activity was of limited duration. A single dose of dexamethasone on $\mathrm{d} 18$ increased GR binding activity in fetal lungs assayed on d $19(226 \%$ of control, $n=2$ ) or 20 ( $154 \%$ of control, $n=2$ ), but not on d 21 $(103 \%$ of control, $n=2)$. Neither the protein:DNA ratio $(97 \pm 6 \%$ of control, $n=3)$, the total protein per $\mathrm{g}$ of tissue (103 $\pm 5 \%$ of control, $n=3$ ), nor the mean total lung weight (102 $\pm 4 \%$ of control, $n=3)$ was altered by dexamethasone treatment.

The organ specificity of the response to glucocorticoid stimulation in utero was tested. Like fetal lung, fetal intestine also demonstrated augmented GR binding activity subsequent to dexamethasone administration in utero, whereas fetal kidney did not show any change (Fig. $5 B$ ). Consistent with previous studies of the effect of glucocorticoid on postnatal lung (10), nonpregnant adult female rat lungs showed decreased GR binding activity (63-66\% of control, $n=2$ ) after dexamethasone exposure.

Fibroblasts from fetal lungs of $20 \mathrm{~d}$ gestation responded to $24 \mathrm{~h}$ of incubation in $10^{-7} \mathrm{M}$ cortisol with increases in GR binding activity (50\%, Fig. 6) and GR protein content (40\%, Fig. 7), even though there was no change in steady-state GR mRNA levels (Fig. 8A). At cortisol concentrations of $\leq 10^{-9}$ $\mathrm{M}$, GR binding activity was not significantly different from control, but a significant increase occurred with cortisol at $\geq 10^{-8} \mathrm{M}$ (Fig. $6 \mathrm{~A}$ ). Similar increases in GR binding activity also occurred in fibroblasts of 19 or 21 d gestation (data not shown). Exposure to $10^{-7} \mathrm{M}$ cortisol for $24 \mathrm{~h}$ increased GR binding, but incubations of $\leq 16 \mathrm{~h}$ did not (Fig. $6 B$ ).

Epithelial cells from lung of $20 \mathrm{~d}$ gestation, in contrast, displayed a decrease $(40 \%)$ in GR protein content in response to incubation for $24 \mathrm{~h}$ with $10^{-7} \mathrm{M}$ cortisol (Fig. 7). However, cortisol did not alter the steady-state GR mRNA content of the epithelial cells, except for a decrease on gestational d 21 (Fig. 8).
A

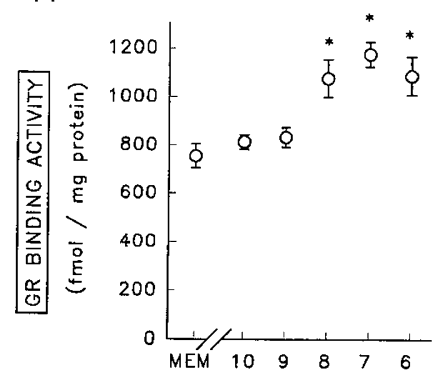

- LOG CORTISOL CONCENTRATION

B

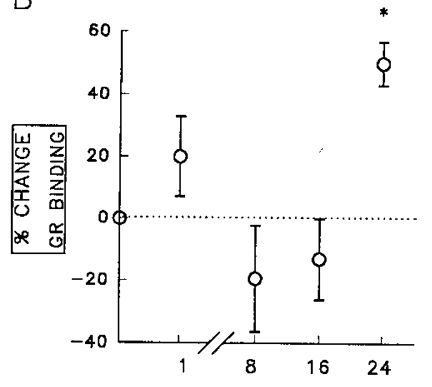

DURATION OF EXPOSURE (HOURS)

Figure 6. Glucocorticoid stimulation of d 20 fibroblast GR binding activity. (A) Dose effect. Stimulation occurs at cortisol concentrations of $10^{-8} \mathrm{M}$ to $10^{-6}$ M. Mean \pm SEM. For each data point, $n=12$ fetuses, from four litters, in two independent experiments. $p<0.05$ by analysis of variance. $(B)$ Effect of duration of exposure. Stimulation occurs after $24 \mathrm{~h}$ of exposure to $10^{-7} \mathrm{M}$ cortisol. Mean \pm SEM. For each data point, $n=4$ independent experiments. $p<0.05$ by analysis of variance.

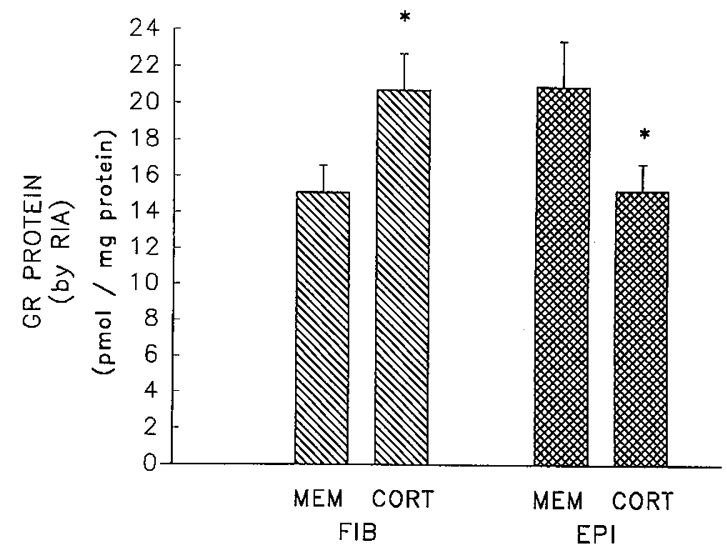

Figure 7. Effect of glucocorticoid on cellular GR immunoreactive protein. In response to cortisol exposure, GR protein content as measure by RIA was increased in d 20 fibroblasts, but decreased in d 20 epithelial cells. *Different $(p<0.05)$ from control value; $n=3$.

To test whether the glucocorticoid treatment used in these studies stimulates lung maturation, we determined its effect on the amount of SP-A protein, a marker of lung maturation known to be responsive to glucocorticoid in rat lung (26-28). The SP-A protein content of $\mathrm{d} 20$ lungs, determined by ELISA, increased after dexamethasone treatment on d $19(260 \pm 31$ $\mathrm{ng} / \mathrm{mg}$ total protein ( $1 \mathrm{mg}$ dexamethasone $/ \mathrm{kg}$ ) versus $149 \pm 26$ $\mathrm{ng} / \mathrm{mg}$ (DMSO control), mean $\pm \mathrm{SEM}, n=3-5$ independent samples, $p<0.05$ dexamethasone versus DMSO control).

\section{DISCUSSION}

The results of the present study indicate that the ontogeny of GR mRNA and GR binding activity in fetal rat lung is cellspecific. Both GR binding activity and steady-state levels of GR mRNA were maximal in lung fibroblasts (and also in whole lung) at $19 \mathrm{~d}$ of gestation, $24 \mathrm{~h}$ before the maximal levels in distal airway epithelial cells. In whole lung, GR functional (hormone binding) activity increased progressively during late gestation, consistent with previously published data $(17,18)$. However, unlike the results of Brönnegård and Okret 

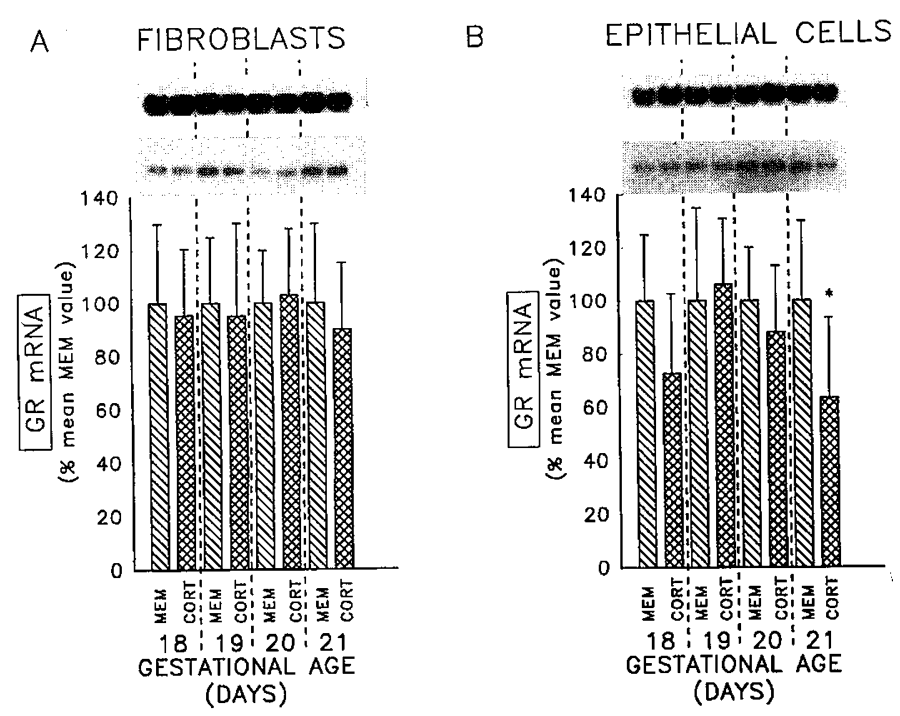

Figure 8. Effect of glucocorticoid on cellular GR mRNA levels during development. (A) Fibroblasts; $(B)$ epithelial cells. Upper insets, autoradiograph of $\beta$-actin mRNA; lower insets, GR mRNA, same representative blot. Incubation in $10^{-7} \mathrm{M}$ cortisol (CORT) did not change steady-state levels of cellular GR mRNA compared with control cells incubated in serum- and hormone-free medium $(M E M)$, except for $\mathrm{d} 21$ epithelial cells. *Different $(p<0.05)$ from control value; $n=3$.

(36), no progressive increase in the steady-state GR mRNA levels was noted.

Previously, Ballard et al. (18) reported specific binding of glucocorticoid to fetal rat lung fibroblasts and epithelial cells. However, the fetal lung epithelial cells they studied were obtained from organotypic cultures incubated for 2-3 wk. Furthermore, lung fibroblastic cells, derived from a 16-wk-old human fetus, were studied from passage 16 to 50 (18). Thus, our present finding of GR $\mathrm{mRNA}$, protein, and specific binding activity in primary cultures of fetal rat lung fibroblasts and epithelial cells, within 1-2 d of killing, may more directly reflect the expression of GR by these cells in vivo. The observed discrepancy between the developmental profiles of GR binding in whole lung compared with those of the individual cell types is most likely due to the thinning of mesenchymal tissue (fibroblasts), flattening of epithelium, and invasion of capillaries which characterize the later stages of fetal lung development.

In the present study, we found that maternal administration of a high dose of dexamethasone $(1 \mathrm{mg} / \mathrm{kg})$ increased whole fetal rat lung GR binding activity, without alteration in GR mRNA levels. In contrast, Brönnegård and Okret (37) observed a $35-50 \%$ decrease in fetal rat whole lung GR mRNA levels after administration of much lower doses $(0.2 \mathrm{mg} / \mathrm{kg})$ of betamethasone. This suggests that a high level of glucocorticoid is required to induce increased GR levels. Because the GR of fetal intestine (like lung, a foregut derivative) was also increased in response to dexamethasone treatment, whereas GR from fetal kidney (of urogenital ridge origin) was not affected, the response of fetal GR levels to glucocorticoid stimulation is tissue-specific. Our data on fetal rat lung growth after antenatal glucocorticoid treatment are in contrast to two previous reports of growth inhibition $(38,39)$. In one study, the dose of dexamethasone was twice the dose used in the present investigation
(38). In the other, the dexamethasone was administered earlier in gestation in three divided doses, and it was given as the sodium phosphate salt in saline s.c. (39).

Within the lung, the response of GR to glucocorticoid stimulation is also cell-specific. Exposure of primary cultures of d 20 fetal rat lung fibroblasts to cortisol increased GR binding activity and GR protein content compared with control cells incubated in serum- and hormone-free medium. The effect on GR binding was dose- and time-dependent. However, identically treated primary cultures of distal airway epithelial cells derived from the same lungs displayed a decrease in cellular GR protein content. Interestingly, on gestational d 20 neither cell type responded to glucocorticoid treatment with any change in GR mRNA levels. These findings suggest a differential posttranscriptional effect of glucocorticoids on GR protein content in fetal lung cells. It is not yet clear whether this is due to altered rates of GR protein synthesis, degradation, or both. The two cell types studied differ in that fetal rat lung fibroblasts reduce inactive intracellular cortisone to active cortisol, whereas the epithelial cells do not (40). Resulting differences in intracellular levels of active glucocorticoid might account for the observed differential effect of the hormone on GR protein levels.

The analysis of glucocorticoid binding activity after in vivo glucocorticoid treatment (1 mg dexamethasone $/ \mathrm{kg}$ ) may be complicated by translocation of the receptor-ligand complex to the nucleus, and also by possible residual tissue dexamethasone interfering with the binding assay in vitro. Even though we have not addressed these issues experimentally in this study, both of these effects would be expected to decrease the apparent binding activity in the in vitro assay, and hence to underestimate the extent to which glucocorticoid treatment up-regulates GR in fetal whole lung or in fetal lung fibroblasts. Our finding of increased GR binding activity in fetal lung fibroblasts was further confirmed by a parallel increase in GR protein. The RIA used to assess cellular GR protein levels has been shown to be unaffected by residual tissue dexamethasone (11). However, because GR protein levels were only measured in the cytosolic component, the epithelial cell GR protein levels may be underestimated due to translocation of the receptor-ligand complex to the nucleus.

In late gestation, glucocorticoids induce production of a differentiation factor, FPF, which stimulates surfactant phospholipid formation in the fetal lung $(1,2,19,21)$. Maximal FPF production by fetal rat lung fibroblasts in response to glucocorticoid stimulation has been reported on $\mathrm{d} 19(1,21)$, coincident with maximal cellular levels of GR mRNA and binding activity. Fibroblast cellular sensitivity to glucocorticoid stimulation should thus be optimal when FPF activity is greatest. Furthermore, contrary to what might have been anticipated based on studies of postnatal lung $(10,16)$, in the fetal lung fibroblast GR function (as assessed by glucocorticoid binding activity) and GR protein content (as assessed by RIA) are enhanced by hormonal exposure. This enhancement, in the context of substantial physiologic increases in circulating glucocorticoid concentrations, may serve to achieve adequate levels of fibroblast GR for the normal production of FPF. 
The maximum observed levels of specific binding of ligand per mg of cellular protein were greater in the epithelial cells (on d 20) than in the fibroblasts (on d 19). This is consistent with direct actions of glucocorticoids on the epithelial cells, independent of mediation by FPF, such as have been suggested with respect to surfactant proteins (26-28). Although mesenchymal enrichment with GR relative to epithelium has been reported (40), our data would suggest that the relative GR content of mesenchyme compared with epithelium will vary as a function of gestational age. Furthermore, in previous studies we have demonstrated relative enrichment in GR in the subpopulation of adjacent fibroblasts compared with peripheral fibroblasts (22). Direct comparison of the GR content of the epithelial cells with that of adjacent fibroblasts is not possible based on the results of the present study of fibroblast cultures containing a mixture of subpopulations.

In summary, we report that the autoregulation exerted on GR by its own hormone during late gestation depends upon multiple factors (including the tissue and cell type, developmental period, dose, and duration of exposure), and occurs principally at a posttranscriptional level. Although glucocorticoid exposure was associated with a decrease in fetal lung epithelial cell GR protein content, it was followed by an increase in fibroblast GR, a finding of potential physiologic importance for the biochemical maturation of the antenatal mammalian lung.

\section{REFERENCES}

1. Gonzales LW, Ballard P 1989 Hormones and receptors. In: Massaro B (ed) Lung Cell Biology. Marcel Dekker, New York, pp 539-589

2. Gross I 1990 Regulation of fetal lung maturation. Am J Physiol 259:L337-L344

3. Gross I, Wilson CM 1983 Fetal rat lung maturation: initiation and modulation. J Appl Physiol Respir Environ Exercise Physiol 55:1725-1732

4. Evans RM 1988 The steroid and thyroid hormone receptor superfamily. Science 240:889-895

5. Gross I, Ballard PL, Ballard RA, Jones CT, Wilson CM 1983 Corticosteroid stimulation of phosphatidylcholine synthesis in cultured fetal rabbit lung. Evidence for de novo protein synthesis mediated by glucocorticoid receptors. Endocrinology 112:829-837

6. Guettari N, Dufour ME, Marin L 1990 Effects of the antiglucocorticoid RU 486 on the initiation of ultrastructural type-II cell differentiation in fetal rat lung. Biol Neonate 58:173-180

7. Guettari N, Marin L, Bourbon J, Dufour M, Rieutort M, Tordet C 1989 Effects of the antiglucocorticoid RU486 on the maturation of fetal rat lung surfactant. Exp Lung Res 15:151-166

8. Miesfeld R, Okrẹt S, Wikstrom AC, Wrange O, Gustafsson J-Å, Yamamoto KR 1984 Characterization of a steroid hormone receptor gene and mRNA in wild-type and mutant cells. Nature 312:779-781

9. Miesfeld R 1990 Molecular genetics of corticosteroid action. Am Rev Respir Dis 141:S11-S17

10. Kalinyak JE, Dorin RI, Hoffman AR, Perlman AJ 1987 Tissue-specific regulation of glucocorticoid receptor mRNA by dexamethasone. J Biol Chem 262:10441-10444

11. Antakly T, Raquidan D, O'Donnell D, Katnick L 1990 Regulation of glucocorticoid receptor expression. I. Use of a specific radioimmunoassay. Endocrinology 126:1821-1828

12. Rosewicz S, Mcdonald AR, Maddux BA, Goldfine ID, Miesfeld RL, Logsdon CD 1988 Mechanism of glucocorticoid receptor down-regulation by glucocorticoids. J Biol Chem 263:2581-2584

13. Svec F, Rudis M 1981 Glucocorticoids regulate the glucocorticoid receptor in the AtT-20 cell. J Biol Chem 256:5984-5987

14. Pépin MC, Beaulieu S, Barden N 1990 Differential regulation by dexamethasone of glucocorticoịd receptor mRNA concentrations in neuronal cultures derived from fetal rat hypothalamus and cerebral cortex. Cell Mol Neurobiol 10:227-235
15. Antakly T, Thompson EB, O'Donnell D 1989 Demonstration of the intracellular localization and up-regulation of glucocorticoid receptor by in situ hybridization and immunohistochemistry. Cancer Res 49(suppl):2230s-2234s

16. Kalinyak JE, Griffin CA, Hamilton RW, Bradshaw JG, Perlman AJ, Hoffman AR 1989 Developmental and hormonal regulation of glucocorticoid receptor messenger RNA in the rat. J Clin Invest 84:1843-1848

17. Ballard PL, Ballard RA, Gonzales LK, Wilson CM, Gross I 1984 Corticosteroid binding by fetal rat and rabbit lung in organ culture. J Steroid Biochem 21:117-126

18. Ballard PL, Mason RJ, Douglas WHJ 1978 Glucocorticoid binding by isolated lung cells. Endocrinology 102:1570-1575

19. Post M, Floros J, Smith BT 1984 Inhibition of lung maturation by monoclonal antibodies against fibroblast-pneumonocyte factor. Nature 308:284-286

20. Slavkin HC, Jaskoll TF, Macdougall M, Zeichner-david M 1985 Hormonal and non-hormonal features of selected epithelial-mesenchymal interactions during development. In: Serrero G, Hayashi J (ed) Cellular Endocrinology: Hormonal Control of Embryonic and Cellular Differentiation. Alan R. Liss, New York, 93-102

21. Smith BT, Post M 1989 Fibroblast-pneumonocyte factor. Am J Physiol 257:L174L178

21.a Cleveland DW, Lopata MA, MacDonald RJ, Cowan NJ, Rutter WJ, Kirscher, MW 1980 Number and evolutionary conservation of $\alpha$ - and $\beta$-tubulin and cytoplasmic $\beta$ and $\gamma$-actin genes using specific cloned cDNA probes. Cell 20:95-105

22. Caniggia I, Tseu I, Han RNN, Smith BT, Tanswell AK, Post M 1991 Spatial and temporal differences in fibroblast behaviour in fetal rat lung. Am J Physiol 261:L424L433

23. Wrange Ö, Okret S, Radojcic M, Carlstedt-Duke J, Gustafsson JÄ 1984 Characterization of the purified glucocorticoid receptor from rat liver cytosol. J Biol Chem 259:4535-4541

24. Bradford MM 1976 A rapid and sensitive method for quantitation of microgram quantities of protein utilizing the principle of protein-dye binding. Anal Biochem 72:248-254

25. Carbone JP, Baldridge RC, Koszalka TR, Bongiovanni AM, Brent RL 1990 Characterization of cytosolic glucocorticoid receptor of fetal rat epiphyseal chondrocytes. J Steroid Biochem 35:495-505

26. Nichols KV, Floros J, Dynia DW, Stavroula SV, Wilson C, Gross I 1990 Regulation of surfactant protein A mRNA by hormones and butyrate in cultured fetal lung. Am J Physiol 259:L488-L495

27. Phelps DS, Church S, Kourembanas S, Taeusch HW, Floros J 1987 Increases in the $35 \mathrm{kDa}$ surfactant-associated protein and its mRNA following in vivo dexamethasone treatment of fetal and neonatal rats. Electrophoresis 8:235-238

28. Schellhase DE, Shannon JM 1991 Effects of maternal dexamethasone on expression of SP-A, SP-B and SP-C in the fetal rat. Am J Respir Cell Mol Biol 4:304-312

29. Laemmli UK 1970 Cleavage and structural proteins during the assembly of the head of bacteriophage T4. Nature 227:680-684

30. Towbin HH, Staehelin T, Gordon J 1979 Electrophoretic transfer of proteins from polyacrylamide gels to nitrocellulose. Proc Natl Acad Sci USA 76:4350-4354

31. Phelps DS, Taeusch HW 1985 A comparison of the major surfactant-associated proteins in different species. Comp Biochem Physiol 82B:441-446

32. Ballard PL, Hawgood S, Liley H, Wellenstein G, Gonzales LW, Benson B, Cordell B, White RT 1986 Regulation of pulmonary surfactant apoprotein SP 28-36 gene in fetal human lung. Proc Natl Acad Sci USA 83:9527-9531

33. Chirgwin JM, Przybyla AE, Mcdonald RJ, Rutter WJ 1979 Isolation of biologically active ribonucleic acid from sources enriched in ribonuclease. Biochemistry 18:5294-5299

34. Snedecor GW, Cochran WG 1980 Statistical Methods. Iowa State University Press, Ames

35. Steel RGD, Torrie JH 1970 Principles and Procedures of Statistics. McGraw-Hill, New York

36. Brönnegård M, Okret S 1988 Characterization of the glucocorticoid receptor in fetal rat lung during development: influence of proteolytic activity. J Steroid Biochem 31:809-817

37. Brönnegård M, Okret S 1991 Regulation of the glucocorticoid receptor in fetal rat lung during development. J Steroid Biochem 39:13-17

38. Adamson IY, King GM 1988 Postnatal development of rat lung following retarded fetal lung growth. Pediatr Pulmonol 4:230-236

39. Schellenberg J-C, Liggins GC, Stewart AW 1987 Growth, elastin concentration, and collagen concentration of perinatal rat lung: effects of dexamethasone. Pediatr Res 21:603-607

40. Torday JS, Post M, Smith BT 1985 Compartmentalization of 11-oxidoreductase activity within the fetal lung alveolus. Am J Physiol 249:C173-C176

41. Beer DG, Butley MS, Cunha GR, Malkinson AM 1984 Autoradiographic localization of specific $\left[{ }^{3} \mathrm{H}\right]$ dexamethasone binding in fetal lung. Dev Biol 105:351-364 